\title{
Forming Plants in Words and Images
}

\author{
Jeanne Fahnestock \\ University of Maryland \\ College Park, $M D$
}

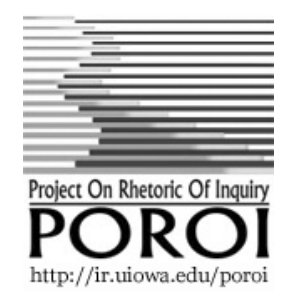

In The Rhetoric of Science Alan Gross demonstrates that classical rhetorical concepts can provide powerful tools for understanding the persuasive work of scientific arguments (Gross, 1990). ${ }^{1}$ In Communicating Science, with Harmon and Reidy, he investigates the history of the scientific article as a genre, showing how it evolved in length, style and presentation from the seventeenth through the nineteenth centuries (2002). In Science from Sight to Insight, with Harmon, Gross provides a syncretic theory of visual communication and argues for the salience of visual modes of persuasion in scientific argument (2013). These key works also illustrate Gross's mastery of different scholarly methodologies, from the theoretically-informed close reading of individual works and visuals, to the comparison of tactics across several works, to the compilation of large databases statistically sampled. Altogether Alan Gross's body of work, including seminal articles and significant anthologies, has established the field of the rhetoric of science and given it methods and a trajectory. No one after him has had to take this ground.

The study presented here follows in Gross's scholarly footsteps. It applies classical rhetorical and dialectical principles to textual analysis; it looks at historical practices in the creation of scientific texts as the initiating and formative precursors of later practices; and it considers visual persuasion. The particular case covered is the renewal of botany in the sixteenth century and the issue examined is how forms of definition prescribed in the humanist discourse arts of the time allowed early modern physicians to

${ }^{1}$ I carried my copy of the newly published Rhetoric of Science, since extensively rewritten as Starring the Text, to a meeting of The International Society for the History of Rhetoric held in Baltimore in 1991. There I attended a special session on the rhetoric of science at which Alan Gross was speaking. For the first and only time in my life, I, a person whom phrenologists would describe as totally lacking a "bump of veneration" approached the author and asked for an autograph on the title page. 
update ancient herbals, assimilate newly discovered plants, and begin to systematize the accumulated body of botanical knowledge. In Germany, the verbal practices underwriting these achievements were rationalized in the discourse arts and combined with new methods of visual representation and reproduction to create the new scholarly herbals appearing from the 1530 on on

When accounting for the complex influences that brought about the new "sciences" of the sixteenth century (astronomy, anatomy and botany), historians of science certainly acknowledge the influence of the humanist-reformed discourse arts (see Serjeantson, 2006, for an overview). The evolving discourse of botany alone has received significant attention from Kristian Jensen (2001), Ian Maclean (2005), Brian Ogilvie (2006), and Sachiko Kusukawa (1997, 2012), as discussed below. But while the importance of rhetoric and dialectic is recognized (see Ogilvie, 118-119), it is not often used in the analysis of early modern texts. Historians tend to ignore the linguistic dimension of this influence, preferring philosophical accounts of argument procedures over discoursebased accounts. And though some scholarship on the influence of the discourse arts on the new sciences exists, no attention at all has been paid to the possible reverse influence, from the new sciences to the discourse arts. The case study offered here suggests how intimate and reciprocal the association was between the language arts and the developing science of botany in the sixteenth century. It can even be argued that the methods of medical botany influenced the methods of definition and description recommended in treatises on the discourse arts, at least in Protestant Germany. And once these expanded methods were taught to succeeding generations, they became the default practices of textual description and, arguably, of the observation that led to that description. Making a case for this influence requires, first, a reminder of the "formal" qualities of the early modern discourse arts and second, an account of the special processes of descriptive defining that were licensed in contemporary dialectical treatises. Next, plant descriptions from contemporary herbals are reviewed to see how they match the dialectical standards for descriptive definition for both known and newly discovered species. The following section then reviews defining through images, based on well-known exemplars produced in the early sixteenth century. The conclusion suggests that the practices in these texts of forming plants in words and images yielded long-term scientific results, enabling systematic botany in the eighteenth century and, arguably, even evolutionary botany in the nineteenth. 


\section{Training in the Discourse Arts}

Every natural philosopher writing in the sixteenth century - from Copernicus and Vesalius in the 1540 s to Brahe and Kepler in the 1580 os and 90 - had a very detailed and very formal training, in Latin, in the allied discourse arts of grammar, rhetoric and dialectic. These arts were transformed between 1480 and 1520 by Agricola, Erasmus, and their humanist followers across Europe. Any university-trained scholar's understanding of language and argumentation was not merely influenced by, it was determined by this humanist construction of Latin into a common instrument of thought and expression. Nor was knowledge of language and of argumentative procedures disjunct. In fact throughout the rhetorical tradition, but peaking in the early modern period, scholars understood forms as content-laden in themselves.

To appreciate the influence of an early modern education in the discourse arts requires understanding the role of linguistic forms in such training since these forms constitute what the linguist Edward Sapir once called the "grooves" of thought (Sapir, 1921, 14-15; 217). Students learning to compose in Latin followed prepared forms at all discourse levels, from the word to the sentence to the passage. These forms could be purely linguistic, or they could specify a function to be fulfilled, or they could even require the production of a certain kind of content. The content-less linguistic forms as extractable, repeatable patterns are ubiquitous in grammar, rhetoric and dialectic, from metaplasms of word formation, to syntactic schemes for sentences, to templates for syllogisms in their various figures. These linguistic forms are "empty"; they require a language about language to come into view. Advice about form could also specify functional slots to be filled, as in the epicheireme calling for certain kinds of support or amplification (Cicero, 101105), or the chreia, one of the early progymnasmatic exercises, where templates call for inserting comparisons, examples, and so on in a certain order (Kennedy, 2003, 15; 76; 97; 139; 193). Such functional forms require a language about argumentation to come into view differentiating what counts as a claim, what as support and what kind of support.

A third kind of form, the least appreciated, specifies the nature of the content required to fill it. The forms in question here include the patterns presented in rhetorical and dialectical treatises for certain topoi. The a fortiori topics A minore and A maiore, for example, where differences of more or less of a phenomenon have to be found, present their users with templates demanding content to follow the phrases multo minus or multo magis (Melanchthon 
1846 [1547], 695). Similarly, the topic of proportion required formulaic phrasing to be filled in with correct numerical analogies (Melanchthon, 1846[1547], 696; una hydria ad duas metretas...sex hydrae ad duodecim metretas). Among these content-defined forms are the "formulae," as Melanchthon called them, for descriptive definitions, which are explained below. These contentspecifying forms require a subject matter language to come into view, and this subject matter language can then become the framework for a body of learning. There may be, in other words, a non-trivial relationship between such forms and the generation of knowledge. The new science of botany in the sixteenth century offers a particular case of synergy between a form specified in the discourse arts, its embodiment in a visual representation, and the management and even generation of knowledge.

\section{Forming Botanical Descriptions}

The initial stimulus for the renewal of botany, as for so many other fields of learning in the early modern period, was the recovery and correction of classical works, in this case by Theophrastus, Dioscorides, Pliny, Galen and others, all appearing in new editions and translations by the first decades of the sixteenth century. But the printing between 1460 and 1530 of the Greek texts and Latin translations of medical herbals like Dioscorides' De Materia Medica, none with illustrations, created nomenclature problems, especially for those interested in the medical uses of plants ${ }^{2}$ (Hoeniger, 1985, 146; Reeds, 1976, 526). How did the names and descriptions in these classical works correspond to living plants with local vernacular names? And how did the plants described by these Mediterranean authors compare to those growing in northern climates? Indeed Brian Ogilvie has described the work of the first generation of sixteenth-century botanists as largely a matter of collation between ancient texts and living plants (Ogilvie, 2006, 34; $127 ; 134)$. There were many uncertainties, and the new botanical treatises published across the century often disagreed with each other over these identifications.

Arguments over whether a plant described in a classical text matched a living plant involved definitions, and the rules and tactics for defining belonged to the disciplines of rhetoric and

${ }^{2}$ The famous illustrated codices of Dioscorides, now in Vienna and Naples, are not the source of these reprints. There were many other extant ms copies of Dioscorides, some illustrated, though without the riveting naturalism of the images in these most famous codices. 
dialectic. All university-trained physicians, including the early cadre of pharmacological botanists, had been trained in these arts. Through the frame of Porphyry's gloss on Aristotle's Categories (relevant to the Topics as well), they knew the five "predicables" (genus, species, differentia, property, accident), and they knew that the definition of a species required the predication of a genus followed by the distinguishing differentia. ${ }^{3}$ Furthermore, in an Aristotelian understanding, a true definition had to express the essence or substance of the thing defined. Among the other predicables, a "property" had to be a feature unique to its species, and though it could be used to construct the differentia of a definition, it did not necessarily capture the essence of a subject. Nevertheless, the test for both a cogent genus/difference definition or a unique property was the same stylistic manipulation of reciprocal predication: Could the claim sustain a conversion in the form of the figure antimetabole? A genuine definition and a genuine property could, as in Porphyry's example of the latter, "If a horse, then hinnability, and if hinnability, then a horse" (Spade, 1994, 10).

These potential conversions, or reciprocal predications, are still important in all sciences where unknowns have to be identified. So for example the definition constructed from a genus term and a unique property - Gallium is an element with an atomic weight of 69.72 a.m.u. - converts to An element with an atomic weight of 69.72 a.m.u. is gallium, and offers an identifying test. However predicating just a genus (Copper sulfate is a compound) or an accident (Copper sulfate is a blue crystal) does not meet the test of conversion in A compound is copper sulfate or A blue crystal is copper sulfate. There are many other compounds and many of these form blue crystals. Here the use of the formal test of reciprocal predication worked in synergy with the systematic development of subject area knowledge. It takes external knowledge, after all, to know that there are other blue compounds in the world. Early modern botanists wanted to know the unique properties of plant species in order to be able to identify plants with certainty, but such knowledge was for the most part inaccessible to them.

More accessible were the "accidents," the qualities taken in by the senses, making up the fifth predicable. Porphyry dissociated these into the separable versus inseparable: "Accident is what

3Early modern students were more likely to learn the five predicables and methods of definition from dialectical treatises of the time rather than from reading the Isagoge itself. 
comes and goes without the destruction of the substrate. It is divided into two kinds. One kind of accident is separable and the other inseparable. Thus sleeping is a separable accident, whereas being black is an inseparable accident of the crow and the Ethiopian" (Spade, 1994, 11). The difference between the two is simple: an inseparable accident is always present in its subject and a separable accident is not. Copper sulfate is blue predicates an inseparable accident, but Copper sulfate is on the third shelf in the storeroom states an easily changed separable accident, and such separable accidents, useful as they may be for identifying things in particular contexts, cannot form definitions, a rule with the authority of Aristotle who clarifies in the sixth book of the Topics that "the differentia of a thing cannot both belong and not belong to it" (Aristotle, 1984, I, 243).

It is easy to dismiss separable accidents like "on the third shelf" from the work of definition. But inseparable accidents always belong to a species. How then are inseparable accidents any different from properties which are also always present in a species? Why are they also ruled out for conversion-sustaining definition? The answer is that an inseparable accident, like having a blue color, is not unique to its subject the way a true property is (like an atomic weight or a spectrographic signature to use contemporary examples). In the case of defining plants, this problem of the non-uniqueness of inseparable accidents is acute because any particular leaf shape and size, any flower color, and any root or stem type is likely to be shared with another plant. So no inseparable accident, on its own, can serve as the differentia in the definition of a plant, or of anything else.

But a solution to the problem of defining and identifying through inseparable accidents is possible. Though no single inseparable accident may be uniquely and hence convertibly predicated of its subject, a collection of them might be so that their assemblage could add up to the differentia creating a convertible definition. Furthermore, what is defined in dialectic as an inseparable accident is typically a quality salient to the senses such as color, shape, texture and taste. So anyone listing multiple inseparable accidents of an object will in effect describe it in the act of defining it - or define it in the act of describing it. And, according to Porphyry, extending Aristotle, accidents can include differences in degree, namely comparisons about more or less of a feature (Spade, 1994, 18). This resource will become a mainstay in descriptions of allied species when observers note that one plant is taller or has hairier leaves than another etc. 
The solution that salvages inseparable accidents for arguments from definition has been attributed to Boethius in De Topicis Differentiis in a passage discussing the variety of topics concerned with definitions:

Definition differs from description because a definition contains genus and differentiae; a description comprises understanding of the subject, either by means of certain accidents producing one property or by means of the differentiae of the substance (substantialibus differentiis) brought together apart from the appropriate genus (Stump, 1978, 49-50).

When Boethius equates a collection of accidents with a property - "certain accidents producing one property" - he is saying that such a collection meets the standard of reverse predication. When he talks about such a collection producing a differentia apart from a genus, he means that a description can simply list features without placing an item in a genus. 4 Overall, Boethius licenses two standards in definition, one with Aristotelian genus/difference rigor and the other laxer and more functional, compiled from several inseparable accidents and amounting to a description. 5

A clearer characterization of pragmatic defining by a collection of enduring accidents, and one that takes this distinction into the early modern period, is found in Rudolph Agricola's influential late fifteenth-century De Inventione Dialectica under the topos of definition. (Peter Mack has drawn attention to Agricola's comments in this key passage [Mack, 1993, 151-56]). After Agricola acknowledges the standard method of defining with genus and differentia, he points to the lack of true differentiae, making it

4Further passages in Boethius legitimize definition from accidents as description: "If the argument is taken from the things themselves, it must be taken from their substance, from the things that follow from the substance, from the things that are inseparable accidents-those that adhere and cannot be or generally are not separated or disjoined from their substance. Those which are drawn from their substance consist in description, definition, or in addition, explanation of the name" (Stump 1978, 60; see also 73, 74 [in the diagram of Themistius' topics]).

5This distinction between definition and description is probably not, however, attributable solely to Boethius. A distinction between definitions based on substance and other discursive forms was worked out by the rhetorician Victorinus several decades earlier in his $D e$ Definitionibus. This work lists fifteen methods of definition, only the first concerning the substance of the thing defined (Stangl, 1888, 33). 
necessary to construct definitions that at least approach the truth. Such approximations, he says, require circumlocution in speaking [loquendi circuiti], collecting many details which the thing is known to possess and which, when joined, create a certain property. Agricola offers as a clarifying example the definition of an ass as an animal "solid-footed, large-eared and fecund." He points out that none of these features belongs to the ass alone: The mule and hare are long-eared and all animals are fecund. But "solid feet" excludes all animals except the horse and mule; "long-eared" then excludes the horse and "fecund" the mule. "At last," he says, "as with steps that which is defined is reached" (Agricola, 1563 [1485], 41). Agricola does not use forms of the term accidens in this passage, but any feature not unique to a species would be understood as belonging to that category. Agricola is also aware that these definitions are in effect descriptions, but he wants to distinguish these defining descriptions from other kinds: "For the description which poets and orators sometimes use expresses a thing more verbosely, nor is it used to express what a thing is but what kind it is, as it places it before the eyes for inspecting." (Agricola, 1563[1485], 42). In this difference between what and what kind Agricola is referencing the "essence" requirement for definitions as well as the stasis distinction in rhetoric between the definitional and qualitative stases. ${ }^{6}$ In formal linguistic terms, however, the descriptions themselves arguing for what or what kind cannot really be distinguished, though Agricola suggests that evocative poetic descriptions tend to be longer.

The term descriptio used in these passages from dialectical treatises by Boethius and Agricola was of course also a term found in rhetorical treatises as a label for a functional form, a form widely noted in manuals and figure lists under various names from antiquity through the early modern period: hypotyposis, demonstratio, descriptio, tractatio (Sonnino, 1968). In the progymnasmata also, description, or ekphrasis, was a distinct compositional exercise (Kennedy, 2003, 45; 86; 117; 166; 218), and though plants were rarely specified as subjects for such exercises, Libanius did produce partial descriptions of the date palm and apple tree embedded in his sample encomia (Gibson, 2008, 261-

${ }^{6}$ Porphyry, following Aristotle in the Categories, distinguished between predicables that concern what a thing is versus what kind or what manner of a thing it is. "For to the question what manner of thing a man is, we say 'rational.' And to the question what manner of thing a crow is, we say 'black.' (Rational is a difference, and black an [inseparable] accident.) But when we are asked what a man is, we answer 'animal.' (The genus of man was animal.)” (Spade 1994, 3). 
266). Erasmus also listed Pliny's many descriptions of living things as examples of such visualizations in Book II of De Copia (Erasmus, 1963 [1514/1534], 50). There are then converging or overlapping accounts in rhetoric and dialectic of functional descriptions, even descriptions of plants, serving arguments in the definitional and qualitative stases. Early modern students would both practice the textual routines of description in their compositional exercises and learn their philosophical uses in their study of dialectic.

Melanchthon recorded his great admiration for Agricola in an encomium on his life, derived in part from conversations he had in Tübingen with elderly scholars who had known Agricola. He even credited Agricola with botanizing in Italy while he was a student of Theodore of Gaza, the translator of Pliny (Reeds, 1976, 527). But Agricola's Dialectica has very few examples from the domain of natural history and those it has, like defining an ass, are traditional. And while Agricola separated oratorical from dialectical definitions on the basis of function, Philip Melanchthon, well known for fusing rhetoric and dialectic, combined them. Indeed in his final and fullest rhetoric text, Elementorum Rhetorices (1542), he claimed that "Definition" as a means of amplification "has here [in rhetoric] the same meaning altogether as in dialectic" (LaFontaine, 1968, 279: "Definitio prorsus hic significant idem quod dialecticis [sic]," translation modified; see also LaFontaine, 1968, 82).

Most important for the case at hand, Melanchthon specified a distinct method of definition from combined inseparable accidents and he applied it to botanical description, in effect both reflecting and licensing the usage of this technique in herbals. Melanchthon's comments and application are found in the four dialectical treatises that he wrote spanning his long career at the University of Wittenberg. The first appeared in 1520 just two years after he came to Wittenberg as a professor of Greek and at a time when he was also required to lecture on Pliny's Natural History. In the first book of this brief dialectic, Melanchthon distinguishes definitions of terms from definitions of things, and gives four forms of the latter: from essentials or properties, from causes, from division into parts, and finally,

The fourth type of defining [is] definition based on accidents, when many added forms describe a thing in some manner ... Among these we frequently use genus with accidents, as the Halcyon is a bird a little larger than a sparrow, with a predominantly blue color, with purples and whites mixed in the wings, with a slender and elongated head and throat. Larch wood is honey colored, imperishable, with no easily split cracks. Of 
animate beings, of trees, of gems, of plants, and of similar things, definitions are sought from this type, and we use this type of defining more frequently because the human mode of cognition generally assembles a certain image of a substance from many accidents. Substances themselves are otherwise unknown. For you will not distinguish between Cato and Julius unless you collect distinctions from the figure, body type, face, voice, stature, walk and age.

You have the formulas [formulae] of definitions which I urge you to practice diligently and accurately, because a method of definition is necessary in the highest degree, not only for judging axioms but also for inventing arguments

(Melanchthon 1521, Biiv; the reference to a mental image here will be discussed below). 7

In his second dialectical treatise written in 1528 , the connection to botanical description is stronger, and as examples of definition from combined accidents he cites " ...the definitions of plants in Dioscorides and Pliny, such as the Narcissus: It is a flower, similar to a crocus, three-fourths stem, flowering in the month of August, coming after all other flowers" (Melanchthon 1529, E1v). And again for Melanchthon, this type of defining is preferable to a search for elusive substances: "Moreover we should use this type of definition often because accidents show us substances otherwise unknown"

7Quartum finiendi genus, definitio constans accidentibus, ubi multae adciticiae formae rem quampiam describunt,...; In his crebro utimur genere cum accidente, ut Halcyon avis est paulo amplior passere, colore caeruleo ex parte maiore, tantum purpureis et candidis admixtas pennis, collo gracili ac procero, etc. Larix lignum est mellei coloris, immortale, nullisque fissile rimis. Animantium, arborum, gemmarum, herbarum, et similium rerum finitiones ex hoc genere petuntur, atque hoc finiendi genere crebrius utimur, quod modus humane cognitionis ferme ex multis accidentibus unam quandam substantiae imaginem colligit. Caeterum substantiae ipsae ignorantur. Neque enim inter Catonem et Iulium internosces, nisi ex figura, habitu corporis, oris, voce, statu, gressu, aetate, discrimina colligas.

Habes definitionum formulas, quas ut diligenter et accurate exerceas, adhortor, quod ratio finitionum apprime necessaria sit, cum ad iudicando axiomata, tum ad argumentorum inventionem ... (Melanchthon 1521, Biir). 
(Melanchthon, 1529, E1v). ${ }^{8}$ In these first two treatises, Melanchthon does not refer to such definitions as formae but as formulae, adding the diminutive $u l$ to create a cognate term that suggests a brief set form or phrase, a template for content (Melanchthon, 1521, Biii; 1529, D3v). The phrase "Formulae Definitionum" [Formulas of Definitions] also appears as a heading in a third dialectical treatise under Melanchthon's name, published in Wittenberg in 1541 with the assistance of his colleague Paul Ebers (Dannenfeldt, 1972, 227). This treatise, though perhaps augmented from material in Melanchthon's lectures, repeats the content in the first two on the tactics for defining things, including definition form a collection of accidents (Melanchthon, 1541, 7576). But when reviewing the kinds of qualities that count as accidents (color, taste, and sense to the touch), this 1541 version, and this version alone, includes a long list of color terms that would be useful to anyone trying to describe plants (Melanchthon, 1541, 36).

Melanchthon produced his final and most extensive dialectical textbook in 1547; this work is addressed not to students, like the first two, but to colleagues and fellow teachers of dialectic. In the intervening years, the Wittenberg medical curriculum had been expanded to include pharmacological botany, and new botanical treatises began to appear that are now famous, both for their naturalistic images of plants and for their increasing inclusion of new species (see below). The physician-botanists producing these and later works had more than a passing connection to Melanchthon and his circle at Wittenberg as Karl Dannenfeldt's research has revealed (Dannenfeldt, 1972). Leonhart Fuchs was his correspondent through the 1530 s and 1540 os and Charles L'Ecluse, or Clusius, was his student (Ogilvie, 2006, 64; 284). Camerarius the Younger was the son of his best friend, and the gifted Valerius Cordus, who is considered by historians to be the most scientifically

${ }^{8}$ Quintum genus est, definicio [sic] ex genere et accidentibus collecta, ut sunt herbarum definitiones apud Dioscoridem et Plinium, ut Narcissus, est flos similis Croco, caule dodrantali, florens mense Augusto, postremus omnium florum. Hoc genere definitionum utimur in describendis personis, ut apud Homerum Thersites describitur, strabis oculis, gibbolsus, garrulitate scurrili. Est autem nobis ideo saepius hac forma definiendi utendum, quia accidentia ostendunt nobis substantias alioqui ignotas, per haec Malvam a Marrubio, Cygnam a Corvo, Pompeium a Iulio, in summa res inter se omnes discernimus (Melanchthon, 1529, E1v). 
inclined of this generation, was his colleague at Wittenberg in the early 1540 .

Given these connections among German academics and botanizing physicians, it is perhaps not surprising that the 1547 treatise has many references to medicinal plants (see for example 1846 [1547], 520, 522, 612, 621, 653, 710, in addition to those cited below). In fact the changes and new emphases in this text are arguably a response to the new botany. For example, when discussing differentia and properties in Book I, Melanchthon repeats that everyone knows that differentia are properties, but that when unique properties are unknown, distinctions of things can come from "an accumulation of accidents, as in the descriptions of plants"(Melanchthon, 1521, 522: "ab accidentium coacervatione, ut in descriptionibus plantarum;" this section is followed by a discussion of the difference between separable and inseparable accidents). In the section on "What is called a definition collected from accidents?" Melanchthon uses a more detailed example than he used in 1521 or 1529 , one closer to those found in contemporary herbals:

A definition collected from an aggregation of accidents is a text [oratio] attaching to the genus or species either the proper accident of the thing [i.e. a unique property] or such a collection of common accidents so that it distinguishes that thing from others ... Many, moreover, use this form in descriptions of plants. Most well known to all is the shrub which bears a fruit, which in our language we call Heimboten. For this fruit the name is Cynosbatos. Its definition is such pertaining to this fourth form: Cynosbatos is a shrub larger than a bramble, in the form of a tree, with thorns around hardy twigs, bearing a fruit with a nut like that of olives, but tinged with red when it ripens, by nature resembling wool on the inside, etc. 9 (Melanchthon, 1846 [1547], $567-568) .{ }^{10}$

${ }^{9}$ Cynosbatos is an alternate for the capparis or caper (see the translation of Dioscorides by Ruel, 1516, 56). However, Melanchthon's definition only matches Dioscorides description of the capparis in the detail of the fruit first resembling an olive. Cynosbatos is also mentioned in Pliny (Book 16, Ch. 71) as an alternate name for the dog-rose. It is unclear which plant Melanchthon has in mind or whether he wrote this description himself. 
As an even more important sign of influence from the new botany, in the fourth book of this treatise Melanchthon adds two new loci that did not appear in his two earlier textbooks on dialectics. The first of these, "Adjacents or Adjuncts," has a label also found in classical manuals like Cicero's Topica, where, however, it is defined for forensic uses as the circumstances surrounding an event (Melanchthon, 1846[1547], 418-419). In Melanchthon's 1547 Erotemata Dialectices it is identified as the source for arguments derived from inseparable or perpetual accidents. Again, the prototypical example of this locus is the defining description of plants:

The next locus prescribes considering the perpetual accidents of a species, and it is the locus close to Property, because the accumulation of perpetual accidents is in fact the property of a species, just as we distinguish glykyrrisan [licorice] from other roots by its figure and sweetness. The rule handed down by Aristotle is useful. Given a species, the perpetual accidents should be sought next, as writers do in the description of plants ... Given a species, the adjacents and adjuncts are posited at the same time, and in turn, destroy the species and at the same time the adjacents and adjuncts are destroyed (Melanchthon, 1846 [1547], 691-92). ${ }^{11}$

${ }^{10}$ Definitio collecta ex coacervatione accidentium est oratio generi vel speciei adiungens vel propria accidentia rei, vel talem coacervationem communium accidentium, quae discernat eam rem ab aliis, ut: Ignis est elementum calidum et siccum, et levitate omnibus antecellens. Multum autem hac forma utimur in descriptionibus plantarum, item in individuorum, ut personarum discriminibus indicandis, ut: Mitionem et Demeam discernunt accidentia. Notissimus omnibus est frutex, qui fert fructum, quem nostra lingua vocamus heimboten. Huic frutici nomen est Cynosbatos. Definitio talis est, pertinens ad hanc quartam formam: Cynosbatos est frutex maior rubo, arboris instar, aculeis circa virgas robustis, fructum ferens similem nucleis olivarum, sed rubentem cum maturescit, lanea intus natura, etc. (Melanchthon, 1846 [1547], 567-568).

${ }^{11}$ Sequens locus iubet perpetua accidentia specierum considerare, estque locus hic vicinus proprio, quia perpetuorum accidentium coacervatio est re ipsa speciei proprietas, ut: $\gamma \lambda \cup \kappa v \rho \rho ı \varsigma \alpha \nu$ discernimus ab aliis radicibus, figura et dulcedine. Utilis est regula ab Aristotele tradita: Posita specie mox perpetua eius accidentia quaerenda esse, ut faciunt scriptores in plantarum descriptione. . . Posita specie simul ponuntur adiacentia et adiuncta, et rursus: Destructa specie simul destrunntur 
The next new locus, "Communiter Accidentia" or "Accidents in Common," is devoted to separable accidents which usually though not inevitably occur and so may support an inference. According to Melanchthon, these produce weaker arguments than inseparable accidents do, but their appearance can be used in support of certain probable causal claims such as the prediction that indigestion will, usually if not always, impede the "heat" in the ventricle (Melanchthon, 1846 [1547], 693). These two new loci offer evidence of the alteration of the classical topical tradition to accommodate the argument practices of sixteenth-century natural philosophers.

Melanchthon's distinctions among types of definition and loci, and the botanical examples he uses to illustrate them, provide one source of evidence for the reciprocal connections between natural philosophy and the discourse arts in the sixteenth century. His dialectical textbooks, especially the 1547 version, circulated widely in Protestant schools and universities in the second half of the sixteenth century (Green and Murphy, 2006, 299-301). But Melanchthon's familiarity with the natural philosophy of his day, extensive as it was, was primarily scholarly. Another author of a dialectical textbook at the time was a practicing physician as well as a humanist professor at the University of Frankfurt on the Oder. This humanist physician, Jodocus Willich, also wrote an Erotematum Dialectices Libri Tres that includes a division of accidents into the separable and inseparable as well as the same four tactics of defining things, culminating in the fourth type, the definition from a collection of accidents: "ex genere \& congeries accidentium constatur" (Willich, 1540, 19; 76). As an example of this fourth type, Willich offers a paraphrase of the full description of glycyrhizza [licorice] found in Dioscorides. Willich's textbook of 1540, reprinted several times, may have been in Melanchthon's mind when he briefly referred to the definition of the glycyrhizza in his new locus of "Adjacents and Adjuncts" (see quotation above). Willich does not expand the loci but his text does contain a further refinement in listing a second type of definition from accidents that clarifies not what but what kind a thing is, putting the "poetic" definition distinguished by Agricola within the domain of dialectic. ${ }^{12}$

adiacentia et adiuncta. Sic contra, posita coacervatione adiacentium ponitur species, ut fit in descriptione plantarum. (Melanchthon 1846[1547], 691-92)

${ }^{12}$ As examples, Willich lists the fish in Oppianus, plants, shrubs and bushes in Theophrastus, animals in Aristotle and Albertus Magnus, metals in Galen, stars in Ptolemy, and "the aratum and manilium, plants 
In contrast to the dialectical textbooks from Melanchthon and Willich, both thoroughly knowledgeable in the natural history of their day, other contemporary dialectics do not include definitional formulas or new loci based on inseparable accidents nor any examples of botanical descriptions. The Elementarius Dialectice of Johannes Eck, published four years before Melanchthon's first text, is very much in the scholastic tradition, a brief reprise of Aristotle's Organon using traditional examples (Eck, 1517). At the opposite end of the spectrum is the very expansive dialectical treatise by Johannes Sturm, which does include a novel third book on Euclidean demonstration, but which also lacks attention to inseparable accidents among definition tactics and loci, as well as botanical examples (Sturm, 1566). The popular dialectical textbook of Johann Caesarius, first published in 1525, does distinguish inseparable from separable accidents but does not link them to definitions and goes so far as to say that descriptions are fine for rhetoricians but not for philosophers (Caesarius, 1525, 156-157). It seems likely then that the changes to the art seen in Melanchthon and Willich stem from their exposure to the revived natural history, and especially botany, of their day.

\section{Descriptive Definitions in Early Modern Herbals}

Recovering strategies from Boethius and Agricola in his first two dialectical treatises, Melanchthon licenses definitions based on perpetual, inseparable accidents and their use as defining descriptions of plants. He does not see himself as innovating in this characterization but as restoring and reaffirming the practice of descriptive definition canonized by its use in Pliny and Dioscorides. Melanchthon's dialectical textbooks from the 1520 s precede the new sixteenth-century herbals by Brunfels (1530) and Fuchs (1542) that are seen as milestones in the history of botany. His dialectical

in Dioscorides" (Willich, 1540, 79-80). Thus Dioscorides' practice exemplifies two methods of definition. These plants are however, not listed in Dioscorides under those names.

Peter Ramus, whose pared down dialectic was first published in French in 1555, does not distinguish types of accidents or expand the loci, but he does distinguish true definitions from the lengthier and celebratory descriptions typical of poets. And after a long example of such a description from the Aeneid, he acknowledges briefly that "telles sont souvent les description des plantes, arbres \& animaux es philosophes" (Ramus, 1555, 60). Ramus's dialectic was also in substantial circulation in the Protestant north, especially in England and even New England, throughout the seventeenth century. 
textbook of 1547, which adds the new loci, comes after those works but before an outpouring of similar ones. Did the verbal descriptions in these herbals match the tactics that Melanchthon defended and that he found in classical sources? What follows is a selection of passages describing a plant known as prassion in Greek, marrubium in Latin and horehound in English; it appears consistently in the herbals, and is a plant that Melanchthon mentions in passing (Melanchthon, 1541, 33). The passages quoted illustrate the actual practice of descriptive defining in sixteenthcentury herbals and furthermore show the persistence of a formula based on inseparable accidents in the definitions of new varieties discovered across the sixteenth century.

The first of the new herbals is Otto Brunfels' Herbarum Vivae Eicones of 1530 (Living Images of Plants or Images of Living Plants). It contains striking naturalistic illustrations (see below), but while the images are new, the text itself consists of excerpts from classical treatises, always beginning with Dioscorides' verbal description of the plant, inevitably also a definition complied from a collection of inseparable accidents as approved by Melanchthon. Here is Dioscorides' description of the marrubium from a widely used 1516 Latin translation of the Materia Medica. It is left in the original Latin to facilitate comparison.

Frutex est ab radice ramosus, candicans, subhirsutus, quadrangularibus ramis. Folium pollicem aequat, subrotundum, hispidum, rugosum, gustu amaro. Semen in caulibus, et ex intervallis flores verticillato ambitu, asperi. Nascitur propter aedificia, \& ruderata loca (Ruel, 1516, 79).

Brunfels changes the wording a bit but has nothing to add to this description:

Marrubii descritio secundum Dioscoridem lib. 3 Frutex est ab una parate ramosus, hirsutus, albescens, quadrangulis caulibus, foliis humano pollici similibus, paulominus que rotundis, hirsutis, rugosis, sapore amaro. Semen per intervalla in caulibus illi est. Flores asperi, verticillorum figura. Nascitur circa areas domorum, \& inter rudera (Brunfels, 1530, 160).

... according to Dioscorides Bk 3. It is a shrub branching from one source, bristly, light-colored, with quadrangular stalks, with leaves like human thumbs [a comparison for size], smaller and round, bristly, wrinkled, with a bitter taste. The seed appears in intervals along the stem. The flowers sharply pointed, in 
the figure of little whirls. It grows around the sites of houses and among rough places.

Twelve years later, Leonhart Fuchs, in perhaps the most ambitious herbal of the century (discussed below), essentially paraphrases this definition, repeating terms such as verticillatim, "like little whirls," which become part of the formidable special lexicon of botanical Latin (e.g., verticillasters, meaning "aggregates of little flowers").

Dioscorides and other ancient authors knew of two species labeled marrubium (the marrubium proper, sometimes called a white marrubium, and a black marrubium, also called ballot or now ballota nigra [Ruel, 1516, 79]). But newly observant botanizing physicians in the sixteenth century accumulated more varieties over the decades that had not been mentioned in classical sources. Melanchthon's former pupil Charles L'Ecluse, for example, traveled through Austria and Hungary deliberately looking for new plants, and in an herbal published in 1583 he recorded another type of marrubium that he was sure no one had described before, one with narrower leaves and bushier stalks branching from the roots.

On the Pannonian Marrubium

The common marrubium is rarer in Austria and Pannonia, and is found springing up spontaneously in no more than a few places. But a certain other type is most numerous which has been described by no one that I remember. Many stems spring from the same root, intermittent, quadrangular, sturdy, abundant, divided into many wings: the leaves arising from single nodes, two by two, in opposite positions, two inches long, one wide, serrated on the edge, almost similar to the common marrubium, but narrower, and exactly circular growing out a little in breadth from the pedicle, and gradually spun into a fine point, altogether gray, with a pleasant odor and a warm and bitter taste: flowers white, similar to the marrubium, emerging from a soft and gray calyx; the image of small whirls [verticillasters], they circle the highest stalk and highest branches: the root is similar to the common [marrubium] from which each year new and more numerous stolens [transverse roots] spring (L’Ecluse, 1583, 588-590).

Also in the later sixteenth century, Rembert Dodoens notes the two types of marrubium known from antiquity, but he is also aware of still other varieties, and he writes a description in fresh language 
that nevertheless follows the same content-ordered form as the previous ones.

The marrubium properly called, grows several quadrangular little stalks, low-footed, and with thin, whitish down: leaves at intervals in pairs, almost round, rough, with a serrated edge, and themselves with whitish down in maturity. Little flowers in some number with pointed almost white receptacles circle the stalk in little whirls. The seed almost round, bitter tasting, the root in darkish fibers. The entire plant has a sweet and pleasing odor and emits a scent not unlike musk, especially in winter months (Dodoens, 1583, 88).

The stylistic form, or formula, of all these descriptive definitions includes keywords (root, stem, leaves, flowers) heavily modified from the lexicon of qualities (words for color, form, shape, texture taste), occasional comparisons, and a stereotyped order, all features approximated in Melanchthon's 1547 textbook description of cynosbatos, quoted above. Usually a "genus" comes first according to Theophrastus' broad categories (tree, shrub, bush, plant). Next the stem, leaves, flower, and seeds are described in that order. Overall the descriptive definition takes the form of an incrementum, a series ordered according to growth, though the roots could be mentioned either first or last. These accounts might seem to be based on a listing of parts, but a definition constructed by enumerating parts had to be exhaustive and all the parts are seldom mentioned in any one definition (Melanchthon, 1846 [1547], 672). The repetitious language in these definitions is also understandable given that each individual perpetual accident is understood to appear in other species as well; it is only the unique combination of characters, as they came to be called, that distinguishes the individual species. Most important, the stereotyped formulas of these descriptive definitions had heuristic value. They clearly taught the botanist what to observe and record when encountering a new plant.

\section{Images as Botanical Arguments}

If the goal of definition from inseparable accidents is the accurate identification of a plant through a formulaic description, it seems obvious that the visible plant would far surpass any description in words. And indeed Melanchthon's 1547 Dialectic acknowledges the superiority of a first hand encounter with the immediate thing. In a section distinguishing definitions of words from definitions of things, he writes 
It is the definition of a word when you interpret a word from a foreign language with a more familiar word from our language and you name the genus, as when you say: Centaurium is a plant which we call "tausent gülden" or Aurin; you hear the genus and name as less strange, and yet it can happen that the thing itself is unknown. But if the plant is brought forward and placed under the eyes so that you can consider it, now you have a clear definition. For the ancients said, and it is worth remembering: All intuitive knowledge is definition (Melanchthon, 1846 [1547], 564).13

There are three ways to understand this perspective on visualization as definition in the 1540s. First, it is impossible to read phrases like "placed under the eyes" and not recall the rhetorical goal, specified from Aristotle to Erasmus, of a verbal description that creates a visual impression. With rhetorical skill, a plant can be placed before the eyes in words. A second sense, however, seems closer to Melanchthon's meaning in this passage: What is placed under the eyes for definitive inspection is the physical plant itself. That standard was met in the early sixteenth century thanks to the addition of botany to the medical curriculum; physicians in training at Wittenberg and elsewhere went on what we would now call field trips to collect plants, or they inspected them in university gardens or as dried specimens in herbaria (Ogilvie, 2006, 149-152). But a possible third sense also deserves consideration, for a plant can be placed under the eyes for consideration when it is drawn in a life-lie image that supports its identification. The rhetorical goal of "placing before the eyes" then shifts to the available means for producing and reproducing a lifelike image.

Manuscript herbals were often illustrated; over twenty illustrated mss. of Dioscorides alone survive from late antiquity through the middle ages (Touwaide, 2008, 55). But a justification for using images at all was needed in the sixteenth century, at least for scholarly publications, because of an often-cited passage in Pliny that pointed out the problems with images of plants and their accurate transmission.

13Definitio nominis est, cum peregrinae linguae, et genus nominas, ut si dicas: Centaurium est herba, quam vocamus tausent gülden, vel Aurin, genus et nomen audis minus peregrinum, ac fieri potest, ut res ignota sit. Sed si herba proferatur, ut subiectam oculis intueri possis, iam habes rei definitionem illustrem. Vetus enim dictum est, et dignum memoria: Omnis intuitiva noticia est definitio. (Melanchthon, 1846 [1547], 564) 
... the subject [of medical botany] has been treated by Greek writers, whom we have mentioned in their proper places; of these, Crateaus, Dionysius, and Metrodorus adopted a most attractive method, though one which makes clear little else except the difficulty of employing it. For they painted likenesses of plants and then wrote under them their properties. But not only is a picture misleading when the colours are so many, particularly as the aim is to copy Nature, but besides this, much imperfection arises from the manifold hazards in the accuracy of copyists. In addition, it is not enough for each plant to be painted at one period only of its life, since it alters its appearance with the fourfold changes of the year. (Pliny, 1966, 141-43)

This passage lists the impediments to visualization in a manuscript culture. Just as scribes inevitably introduce copying errors into written texts, those copying images commit similar distortions by making elements of a visual more symmetrical, by smoothing out or embellishing features, and by unconsciously adopting changing conventions of representation. Adding color to an image compounds these problems. And a further complication occurs in the case of plants because static images can never fully represent the seasonal stages of growth and decay.

The advent of printed images, largely from woodblocks in the sixteenth century, would answer some of these objections, and indeed William Ivins argued over fifty years ago for the importance of "exactly repeatable pictorial statements" in communicating and expanding scientific and technological knowledge (Ivins, 1953, 2). But new modes of image reproduction did not bring immediate changes, and indeed the first printed herbals of the late fifteenth century often merely repeated the schematic images found in most manuscript herbals. Below is the illustration of the plantago minor from the Hortus Sanitatis of 1497 (Fig. 1) which shows the triumph of the copyist's imposed symmetry. 




Figure. 1 The plantago minor from the Hortus Sanitatis, 1497 (viiiv).

What was needed was both a new standard in naturalistic representation and an exponential improvement in the art of cutting woodblocks to create realistic images capable of conveying the subtleties of inseparable accidents taken from de novo observations.

It is difficult to date a beginning for "naturalism" in the representation of plants and animals. Art historians have found many isolated exemplars across the centuries satisfying western standards of naturalism in their depiction (see Blunt, 1950, 18-30). The Vienna and Naples codices of Dioscorides dating from the fifth century $\mathrm{CE}$ are triumphs of Byzantine realism; illuminated medieval manuscripts often contain accurate depictions of plants; a manuscript herbal created in Carrara, ca. 1400 has stunningly lifelike images (Smith, 2008, 15-17); William Ivins identifies the popular German herbal the Gart der Gesundheit of 1485 as "epoch making" for its informative images of plants which its author claims to have drawn from the life, though the actual images are rather crudely cut (Ivins, 1969, 34-36). But by the late fifteenth century a new standard of naturalistic depiction did take hold and was combined with improvements in the art of woodcutting to yield "exactly repeatable" true-to-life images. The combination of these innovations can be plausibly traced to the practice of Albrecht Dürer (Hind, 1963 [1935], 379; 386-7). Supervising the woodblock 
cutters in his workshop, Dürer enhanced both the fineness and the density of line and hence the detail that woodcuts could convey, and his own drafting practices conformed to the new naturalistic standard in the depiction of objects in nature, on display in his famous watercolor studies of grasses and animals. Skilled woodcuts of naturalistic drawings represented a stunning shift in a technology of visual reproduction that could both achieve true-tolife representation and be easily combined with printed text.

Virtually every text on the history of botany, of herbals, and of book illustration tells the same story of the dramatic difference in botanical illustration achieved by German printers in the 1530 s and 40s (Blunt 1950, 45-56; Arber, 1912, 47-65). The naturalistic woodcut was brought to the herbal in 1530 by Otto Brunfels' illustrator, Hans Weiditz, who followed Dürer's practice and may have been his pupil (Landau and Parshall, 1994, 237-250; 255). Drawn from nature, Weiditz's images depict the often less than pristine state of the specimen in the hands of the artist (see for example Brunfels, 1530, 63). In dialectical terms, these images include the separable accidents unique to the individual specimen. These details enhance the fidelity of the images to observation and therefore work as evidence for the contemporary existence of the plants depicted. But these separable accidents also compromise the effectiveness of the images in support of identifying definitions.

Both the methods of descriptive definition and the visualization practices in Brunfels's herbal had detractors. Sachika Kusukawa has detailed the pamphlet war conducted from 1530 to 1540 between Leonhart Fuchs of Tübingen, producer of the next realistically illustrated herbal in 1542, and Sebastian Monteaux, a professor of medicine at the University of Paris over how plants should be defined and imaged (Kusukawa, 1997, 2012). In response to a 1530 work by Fuchs correcting errors in plant identification, Monteaux accused Fuchs of basing his definitions of plants on accidents rather than on essences according to the Aristotelian standard. Fuchs defended both his verbal practice as well as the use of images by connecting both modes of description with the usefulness of inseparable accidents:

... [Monteaux] childishly contends that arguments derived from the descriptions of medicinal simples, transmitted by Dioscorides and other ancients, are useless because they do not depend on the genus and differentia of a substance but on genus and accidents which can be present or absent before the corruption of the subject. However, Montuus ignores that not all accidents may be present or absent, but there are certain 
ones that typically adhere in substances so that they are never separated from the thing itself, which in dialectic are called innate, because they are by nature in the subject, as heat in fire, hardness in stone, forms of root, stem, leaves and flowers in plants. And because accidents very obviously reveal substances otherwise unknown to us (for through these we distinguish all things among themselves, like the mallow from the asphodel, the swan from the crow) the form of defining from genus and collected accidents will certainly have the most important uses. For in fact it is a method of human cognition generally to collect one certain image of a substance from many accidents, in the way that Homer did when he described Thersites to have slanted eyes, a pointed head, a humped shoulder, and a clownish garrulity. In short, why would arguments derived by definition from genus and accidents be inefficacious when in general and everywhere we talk periphrastically [circumloquamur] about the differences of things through accidents, nor do many proper names of differentiae exist (Fuchs, 1533, 9v-10; cited in Kusukawa, 1997, 419-420).

Here, in 1533, Fuchs repeats the same defense of forming mental images from accidents that Melanchthon used in 1521, while Fuchs notes the similarity to Homer's practice that Melanchthon in turn repeated in $1547 \cdot{ }^{14}$

In the magnificent herbal he produced in 1542, De stirpium historia, Fuchs corrected the over-particularity of the Weiditz's

14Kusukawa first detailed the debate between Fuchs and Monteaux in an article published in 1997. She identifies Fuchs's persuasive use of pictures to confirm an identification of a plant depicted in his herbal with a plant characterized by Dioscorides; she also cites passages from his defense of defining through inseparable accidents and of using pictures despite the criticisms of Pliny and Galen. She notes Melanchthon's account of definitions based on assembled accidents, but not their source or his new loci or his interest in images. She reprises her 1997 article in a recent book (2012), truncating the references to Melanchthon, citing Ian Maclean's discussions of arguments based on separable versus inseparable accidents and adding the influence of Agricola (Kusukawa, 2012; Maclean, 2005). Jensen disagrees somewhat with Kusukawa's first account of Fuchs's enterprise, but she also emphasizes the importance of the "philosophical" distinction between separable and inseparable accidents" (Jensen, 2001). 
images in Brunfels's herbal. He used a team of three artists - one to paint the plant from life, one to transfer the image to a woodblock, and one to incise it in relief -- to produce idealized, composite images that featured different phases of the plant's life cycle in one specimen, creating the convention of multi-season depiction that still survives. The critical difference between Brunfels' and Fuchs's images is a matter of whether the image, as in Brunfels' case, included separable accidents in the depicted details of the individual specimen's actual condition, or avoided these and included only criterial inseparable accidents, as in Fuchs's case. See Fig. 2. below, comparing their images of the viola matronalis or Geel Violaten in German:
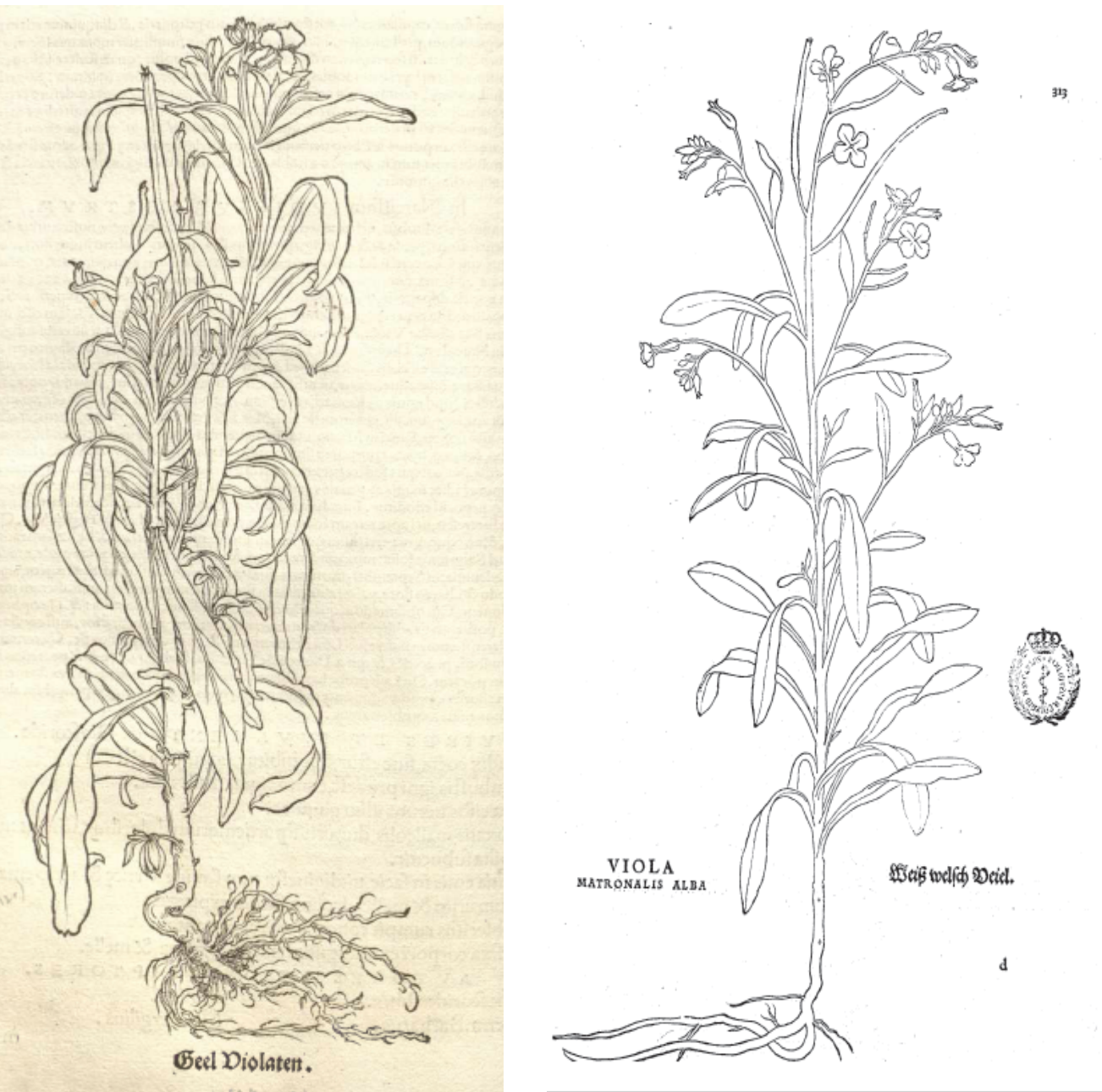

Figure 2. The left hand image is by Weiditz in Brunfels' Herbarum (Brunfels, 1530, 137). The right hand image is from Fuchs's De Historia Stirpium (Fuchs, 1542, 312). This plant illustrates the nomenclature problems of that time and since. What Brunfels and Fuchs call a variety of violet is now commonly called a stock in the genus Matthiola (Meyer, Trueblood, and Heller, 1999, 97). 
Melanchthon would have supported Fuchs's practice since he believed that images as formed in the mind were generalizations created from observed particulars. His discussion of this issue, amounting to a key justification for the argumentative use of images, appears in Book I of his 1547 dialectic in the section on the Predicables addressing the enduring Platonic question, "Are there universal things beyond the understanding as certain Ideas have been conceived to be universal things beyond understanding?"

Whatever thing is truly and positively in nature is something beyond comprehension; it is singular in itself. Things are beyond comprehension: this servant, this man, this horse. But that common image of the stag, which is called the species, is not something beyond comprehension, nor is it, as the Greeks say, hyphistamenon or hypostasis [substance or underlying reality]. But painting that image in the mind is already an act of understanding, which is therefore called general, because it can be applied to many individuals, and carrying around in the mind an image of a stag, it recognizes stags wherever encountered, comparing the figure to the image in the mind (Melanchthon, 1846 [1547], 520). ${ }^{15}$

The generalized image then counts as a representation of a species, and it is worth remembering that in Latin, the root of species (from specere to look at) suggests the thing seen. The image in the mind can be transformed into the image on a page and serve as a source of identification for new encounters. Meeting the new standard of naturalism in the hands of master draftsmen and woodcutters, it can justly support the definition arguments in the new herbals. The definitions through verbal descriptions of the marrubium, quoted above from Brunfels and below from Fuchs, are reprised in the accompanying images.

${ }_{15}$ Quaecunque res in natura vere et positive est quiddam extra intellectionem, est singularis per sese. Res sunt extra intellectionem, hic servus, hic homo, hic equus. Sed communis illa imago cervi, quae vocatur species, non est quiddam extra intellectionem, nec est, ut Graeci loquuntur $\cup \varphi \imath \sigma \tau \alpha \mu \varepsilon v o v$, seu hypostasis. Sed est revera actus intelligendi, pingens illam imaginem in mente, quae ideo dicitur communis, quia applicari ad multa individua potest, ut circumferens in mente imaginem cervi, agnoscit cervos ubicunque oblatos, figuram ad imaginem in mente conferens (Melanchthon 1846 [1547], 520). 


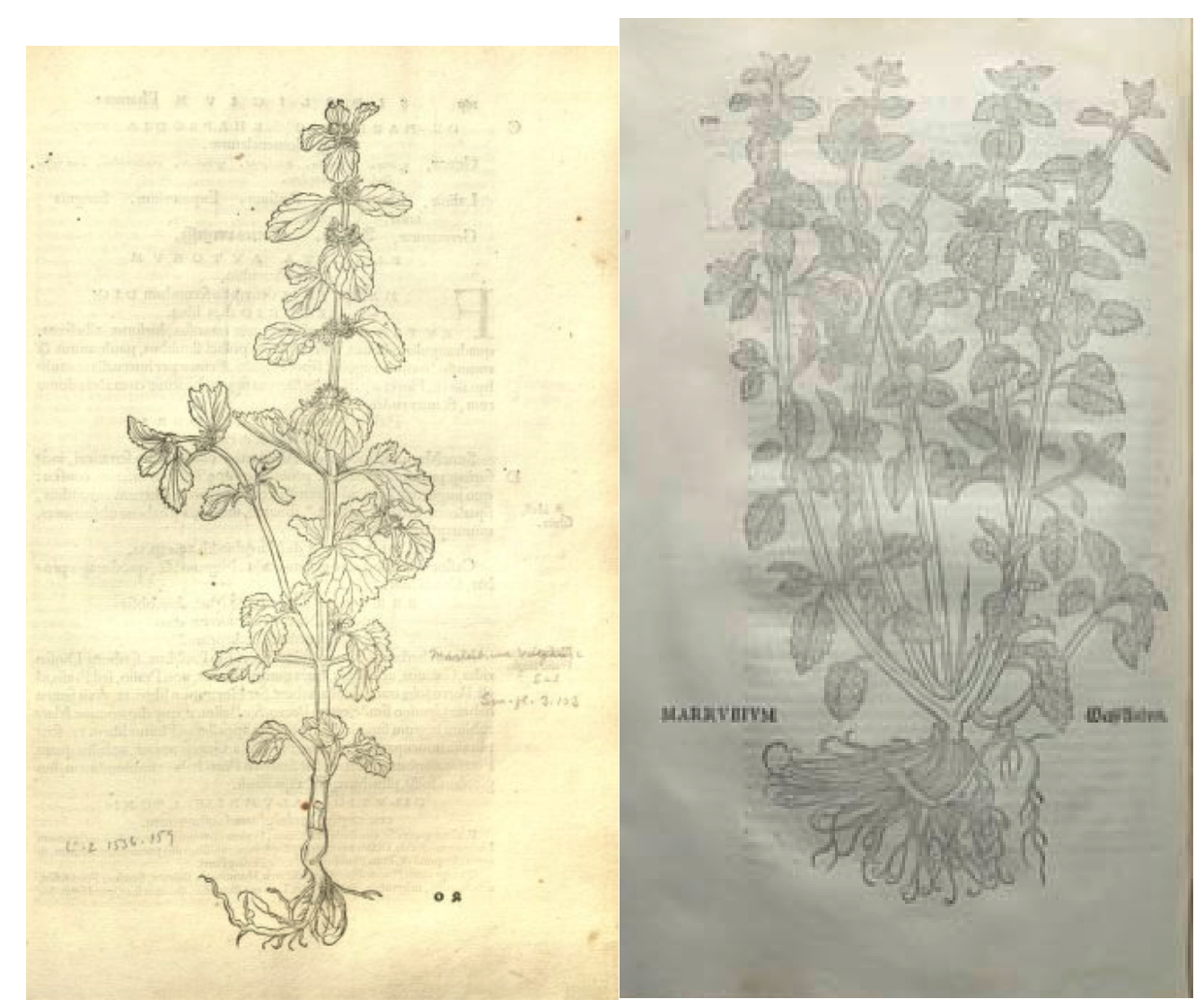

Figure 3. Images of the marrubium from Brunfels (1530,) on the left and Fuchs (1542) on the right. Weiditz' model for the image in Brunfels was a single stalk of what was in reality a bushy plant, more accurately depicted in Fuchs's herbal.

\section{Connecting Words and Images}

The point bears repeating: Coming in an age of correcting botanical knowledge, the images in early sixteenth-century herbals, along with the verbal descriptions, were intended as evidence for the definitive identification of a particular living plant with a classical description/definition. When, in other words, both Brunfels and Fuchs provide an image of the marrubium, it is meant to conform not only with Dioscorides' verbal description but also with the "living plant" that served as its model. Brunfels, however, does not typically connect his text to the images he provides. In his herbal, these two modes of "placing before the eyes" operate in disconnected tandem. Fuchs, on the contrary, very deliberately refers to the accompanying images to make his case for the identity between the ancient descriptive definition and the living plant depicted. Here is his text on the marrubium which can be compared to the excerpts provided above.

De Prasio/Marrubium: Form 
It is a shrub branching from one root, somewhat hairy, whitish, with quadrangular stems. The leaf is equal to a thumb, somewhat round, hairy, full of wrinkles, with a bitter taste. The seed [appears] in intervals along the stalk. The flowers [are] sharp-pointed in the figure of little whirls. This picture [referring to a woodcut appearing on the opposite page, see Figure 3] corresponds accurately to what is called marrubium today; in that it sprouts out from a single root with little branches at an angle, full of down, with leaves almost circular in shape, the size of a thumb, very gray, hairy, bitter, with a milk-white flower in little whirls encircling the stem grasped in intervals, from which grows up a tapering and bitter seed (Fuchs, 1542, 589).

In effect Fuchs writes the same description twice, the first time as a paraphrase from Dioscorides and the second time as an account of the picture on the facing page. By matching these, Fuchs in effect claims that the plant identified verbally by Dioscorides is the same plant he had illustrated. The check on the circularity of his argument is presumably the naturalistic image itself which stands in for the living plant to support the verbal account.

Oddly, Brunfels' practice of not referring to the accompanying image is more typical in sixteenth-century herbals. And, according to Brian Ogilvie, images eventually fell out of favor in serious botanical works by the early seventeenth century (Ogilvie, 2003, 142). The more scientifically ambitious botanical works by Cesalpino and Bauhin are not illustrated, nor are most of the works of the great systematists of the eighteenth century like Tournefort and Linnaeus. Images of plants, however, did not fall out of favor. Woodcuts could not be improved in the sixteenth century beyond the excellence achieved by Weiditz in 1530, because of the roughness of the available paper and the crudeness of the available techniques of inking (Ivins, 1969, 47-49). Engraving became the preferred technology for reproducing naturalistic images, and more accurate and compelling illustrations became possible. But these engravings were also more expensive to produce, so they were more common in special "high end" publications celebrating flowering plants [florilegia] or individual gardens, rather than in herbals or species compendia that would require hundreds and eventually thousands of images.

\section{The Scientific Legacy of Formulaic Definitions}

In the influential dialectical treatises of Agricola, Melanchthon and others, there is ample authorization and some incentive for the 
verbal and visual practices of the sixteenth-century physicians and natural philosophers reviving the study of botany. But the connection goes both ways as Melanchthon's expansion of the loci in his 1547 treatise shows how the discourse arts could also accommodate a new empiricism evident in the expanding plant catalogs published in the sixteenth and into the seventeenth centuries. While the descriptive definitions in these works, all following a prescribed form with ordered content and repetitive terms, may seem uncreative, there were in fact important pay-offs from this formulaic method.

First, the model definition of a plant from a selection of its unchanging accidents made it possible to assimilate the flood of new plants not described in ancient treatises but discovered through expanding trade and travel in northern Europe, the New World and the near and far East (Saunders, 1995, 65). For example, one of the new species recorded by Fuchs in 1542 was sorghum, probably introduced from Africa and at the time called Serpentaria because of the shape of its roots that were thought to have medicinal value. Fuchs knew of no account of this plant among the ancient Greek and Latin physicians, so without a precedent, he was on his own in defining it descriptively:

Form:

The small stem stands firm, thin and rush-like, bare, with many leaves on the bottommost part, with a spiked flower on the vertex, in which a more dilute color of purple inheres: the leaves like sorrel cutting from the earth, from above [are] green and grassy: as for the root, the male somewhat in the manner of a dragon involuted and contorted; the female truly oblong, larger and hairy, outside blackish, inside reddish (Fuchs, 1542, 772-775).

This verbal definition is clearly based on distinctive visible accidents and not on an enumeration of parts. Just enough detail is given for purposes of contrast to distinguish this plant from others like it. Two images are provided of the two varieties, called male and female simply for the sake of differentiation, but there are no references to these images in the text, perhaps because there is no argument to make about the identity of this living species with a classical precedent.

A second benefit from formal definitions occurs when the varieties within a species become obvious in juxtaposed texts, as differences in size or color or leaf shape or other visible aspects are highlighted. When several similar species accumulate, the gradations in differences between them become especially obvious. 
Compiling species lists in the early seventeenth century when thousands, not hundreds of species were known altogether, Caspar Bauhin produces shorter descriptions of two species of just the white marrubium:

White hairy marrubium: grows small stalks a foot long, woody, circular, white, hairy, divided in branches: leaves are almost round, small, rough, notched through the edge, below thick white hairs placed further down, like Gnaphalium, above pliant, wrinkled and blackish: little flowers, as in the common, circle the stalk in whirls.

Curly white marrubium: this with small stalks is woody, circular, white, but the leaves smaller, curly, serrated, each side; in part ash-colored, with no thick rough hairs: little flowers almost white in pointed receptacles circle the stalk in little whirls (Bauhin, 1620, 110, from Latin Prodromos Theatri Botanici Frankfurt).

Bauhin is but a step away from Linnaeus in the Species Plantarum of 1753 . This later work organizes some 10,000 species into classes according to the number of stamens and pistils, but below this later-discredited level, it groups species according to genus and adds a distinctive name, eventually establishing binomial nomenclature. In 1753, the format for each entry does not repeat everything that is common to the genus but only includes a brief description of each species featuring the perpetual accidents that constitute the differentia distinguishing that species from similar ones. Here for example are entries for individual species of Leucadendron; the entries are left in the original Latin for purposes of comparison.

LEUCADENDRON foliis sublatis, ramis determinatis, floribus terminalibus.

LEUCADENDRON foliis sublatis, ramis sparsis, floribus lateralibus.

LEUCADENDRON foliis lanceolatis, florbus oblongis, calycum squamis summis hirsutis.

LEUCADENDRON foliis lanceolatis, floribus oblongis, calycum squamis glabris.

LEUCADENDRON foliis lanceolatis, floribus subrotundis, caule suffruticoso unifloro.

LEUCADENDRON foliis lanceolatis, floribus subrotundis, caule fruticoso ramoso. 
LEUCADENDRON foliis integris, floribus depressis, corollarum limbis cylindricis.

LEUCADENDRON foliis calloso-tricuspidatis involventibus flores laterales.

LEUCADENDRON foliis calloso-tricuspidatis, calycibus turbinatis nudis.

(Linnaeus, 1753, 91-93; each of Linnaeus's descriptions is followed by brief descriptions from other published plant catalogs, not quoted here.)

For Linnaeus, leaf shape creates the first distinction (foliis $=$ with leaves). When species share the same leaf-shape, the description continues until it finds a distinctive difference in the flowers (floribus), their disposition (corollarum $=$ of wreathes), or in the stem (caule) or calyx (calycibus = with calyxes). The prominence given to leaves, breaking the incrementum order of full definitions, occurs because of their consistency through the seasons when flowers or seeds may be absent. The overall effect of this catalog with its parallel, pared-down descriptions is to show the slight branching differences in allied species, an achievement made entirely verbally since the Species Plantarum required no illustrations.

The effect of this standardization into the eighteenth and nineteenth centuries is an often-told story in the history of botany. A systematics based on visible affinities is one benefit. An awareness of environmental influences on plant forms is another, as differences occur in plants growing in different conditions of climate or soil. And eventually, when ever-larger catalogs of allied species, varieties and sub-varieties were amassed in the nineteenth century, a vision far beyond that imagined by sixteenth-century botanists emerged. Poring over the huge compendia of species available in his day, noting the unsymmetrical distribution of species and varieties in various genera, Darwin began to reason that selection pressures had created these slight changes in leaf shape or stem type, and that therefore there is an evolutionary connection from variety to variety and eventually from species to species (Darwin, 1996 [1859], 43-50).

\section{Reference List}

Agricola, R. De Inventione Dialectica Libri Omnes. Cologne: Agrippina, 1563 [1485]. 
Arber, A. Herbals, Their Origin and Evolution: A Chapter in the History of Botany, 1470-1670. Cambridge: Cambridge University Press, 1912.

Aristotle. The Complete Works of Aristotle: The Revised Oxford Translation. In Barnes, J., (Ed.) Vol. I. Princeton NJ: Princeton University Press, 1984.

Bauhin, C. Prodromos Theatri Botanica. Frankfurt, 1620.

Blunt, W. The Art of Botanical Illustration: An Illustrated History. New York: Dover, 1950[1994].

Brunfels, O. Herbarum Vivae Eicones. Strasburg: Schott 1530/1536.

Caesarius, J. Dialectica. Lugduni: Seb. Gryphium. 1551.

Cicero. De Inventione. De Optimo Genere Oratorum. Topica. In Hubbell, H.M. (Trans.) Cambridge, MA: Harvard University Press, 1976.

Dannenfeld, K. H. "Wittenberg Botanists During the Sixteenth Century." In Buck, L. P. and J. W. Zophy (Eds.) The Social History of the Reformation. (Pp. 223-248.) Columbus: Ohio State University Press. 1972.

Darwin, C. The Origin of Species. In Beer, G. (Ed.) Oxford: Oxford University Press, 1996[1859].

Dodoens, R. Stirpium Historiae Pemptades Sex. Antwerp, 1583.

Eck, J. Elementarius Dialectice. Augustae Vindelicorum. 1517.

Erasmus, D. On Copia of Words and Ideas. In King, D.B. and H.D. Rix (Trans.) Milwaukee, WI: Marquette University Press, 1963 [1514/1534]).

Fuchs, L. Paradoxorum Medicinae Libri Tres. Basel: Bebel, 1535 .

Fuchs, L. De Histories Stirpium Commentarii Insignes. Basel: Isengrin, 1542.

Gibson, C. Libanius's Progymnasmata: Model Exercises in Greek Prose Composition and Rhetoric. Atlanta: Society of Biblical Literature, 2008.

Green, L. and J. J. Murphy. Renaissance Rhetoric Short-Title Catalogue. Aldershot, UK: Ashgate, 2006.

Hinds, A.M. An Introduction to a History of Woodcut, Vol. 1. New York: Dover, 1963 [1935].

Hoeniger, F.D. "How Plants and Animals Were Studied in the MidSixteenth Century.” In Shirley, J. W. and F. D. Hoeniger 
(Eds.) Science and the Arts in the Renaissance (Pp. 130-148). Washington: The Folger Shakespeare Library, 1985.

Ivins, W. M. Jr. Prints and Visual Communication. New York: Da Capo Press, 1969.

Jensen, K. "Description, Division, Definition - Caesalpinus and the Study of Plants as an Independent Discipline." In Pade, M. (Ed.) Renaissance Readings of the Corpus Aristotelicum. (Pp. 185-206). Copenhagen: Museum Tusculanum Press, 2001.

Kennedy, G. A. Progymnasmata: Greek Textbooks of Prose Composition and Rhetoric. Atlanta: Society of Biblical Literature, 2003.

Kusukawa, S. "Leonhart Fuchs on the Importance of Pictures." Journal of the History of Ideas 58 (1997): 403-437.

Kusukawa, S. Picturing the Book of Nature: Image, Text and Argument in Sixteenth-Century Human Anatomy and Medical Botany. Chicago: University of Chicago Press, 2012.

LaFontaine, S. M. J. A Critical Translation of Philip Melanchthon's Elementorum Rhetorices Libri Duo (Latin text with English translation and notes). Ann Arbor, MI: University Microfilms, 1968.

Landau, D. and P. Parshall. The Renaissance Print: 1470-1550. New Haven: Yale University Press, 1994.

L'Ecluse. C. Rariorum Aliquot Stirpium, per Pannoniam, Austriam, et Vicinas. Antwerp, 1583.

Linnaeus, C. Species Plantarum, Exhibentes Plantas Rite Cognitas, ad Genera Relatas, cum Diffrentiis Specificis, Nominibus Trivialibus, Synonymis Selectis, Locis Natalibus, Secundum Systema Sexuale Digestas. Tomus I. Holmiae: Laurentii Salvii, 1753.

Mack, P. Renaissance Argument: Valla and Agricola in the Transitions of Rhetoric and Dialectic. Leiden: Brill, 1993.

Maclean, I. "White Crows, Graying Hair, and Eyelashes: Problems for Natural Historians in the Reception of Aristotelian Logic and Biology from Pomponazzi to Bacon.” In Pomata, G., and N. Siraisi (Eds.) "Historia: Empiricism and Erudition in Early Modern Europe. (Pp. 147-179.) Cambridge, MA: The MIT Press, 2005.

Mazzolini, R. G. Non Verbal Communication in Science Prior to 190o. Biblioteca Di Nuncius (Book 11), 1993. 
Melanchthon, P. Compendiaria dialectices ratio. Coloniae, 1521. Dialectica libri quattuor. Wittenbergiae, 1528. Praeceptiones dialecticae. Wittenbergiae, 1541. "Erotemata Dialectices.” In Bretschneider, C.G., Ed. Corpus Reformatorum: Philippi Melanchthonis Opera, Quae Supersunt Omnia. Vol. XIII. New York: Johnson, 1846[1547].

Meyer, F. G., E. W. E. Trueblood, and J. L. Heller. The Great Herbal of Leonhart Fuchs: De Historia Stirpium Comentarii Insignes. Stanford CA: Stanford University Press, 1999.

Ogilvie, B. "Image and Text in Natural History, 1500-1700." In Lefevre, W., J. Renn, and U. Schoepflin (Eds.) The Power of Images in Early Modern Science. (Pp 141-166.) New York: Springer Science, 2003. The Science of Describing: Natural History in Renaissance Europe. Chicago: University of Chicago Press, 2006.

Pliny. In Jones, W.H.S. (Trans.) Natural History. With an English Translation in Ten Volumes. Vol. 7. Cambridge, MA: Harvard University Press, 1966.

Ramus, P. [P. de la Ramee]. Dialectique. Paris: Wechel, 1555.

Reeds, K. M. "Renaissance Humanism and Botany." Annals of Science 33 (1976): 519-542.

Ruel, J. Pedacii Dioscoridis Anazarbei de Medicinali Materia: Libri Quin[que]. Paris: Stephanus, 1516.

Sapir, E. Language: An Introduction to the Study of Speech. New York: Harcourt Brace Jovanovich, 1921.

Saunders, G. Picturing Plants: An Analytical History of Botanical Illustration. Berkeley CA: University of California Press, 1995.

Serjeantson, R.W. "Proof and Persuasion." In Park, K., and L. Daston, (Eds.) The Cambridge History of Science Vol 3. Early Modern Science (Pp. 132-175.) Cambridge: Cambridge University Press, 2006: 132-175.

Smith, P. H. "Artisanal Knowledge and the Representation of Nature in Sixteenth-century Germany." In O'Malley, T. and A.R.W. Meyers (Eds.) The Art of Natural History: Illustrated Treatises and Botanical Paintings: 1400-185o (Pp. 15-32). New Haven: Yale University Press, 2008.

Soninno, L. A Handbook to Sixteenth-Century Rhetoric. New York: Barnes and Noble, 1968. 
Spade, P. V. (Trans.) Five Texts on the Mediaeval Problem of Universals: Porphyry, Boethius, Abelard, Duns Scotus, Ockham. Indianapolis: Hackett, 1994.

Stangl, T. Tulliana et Mario-Victoriniana. Munich: Max Wild'sche Buchdruckerei, 1888.

Stump, E. Boethius's De Topicis Differentiis: Translated with Notes and Essays on the Text. Ithaca: Cornell University Press, 1978.

Sturm, J. Partitionum Dialectarum Libri IIII. Strasbourg: Rihelius, 1566.

Touwaide, A. "Botany and Humanism in the Renaissance: Background, Interaction, Contradictions.” In T. O'Malley and A.R.W. Meyers (Eds.) The Art of Natural History: Illustrated Treatises and Botanical Paintings: 1400-1850. (Pp. 33-62). New Haven: Yale University Press,2008.

Warner, M. F. “The Augmentatio, 1614, of De Bry's Florilegium Novum." Libri. International Journal of Libraries and Information Service (6) (2009): 29-32.

Wagner, P. "Renaissance Readings of the Corpus Aristotelicum Not Among the Herbalists." In Pade, M.( Ed.) Renaissance Readings of the Corpus Aristotelicum. (Pp. 167-184.) Copenhagen: Museum Tusculanum Press, 2001.

Willich, J. Erotematum dialectics libri tres. Strasbourg: Mylius. 1540 . 